Chouliaraki, L. (2006) The Spectatorship of Suffering. Sage Publications.

Powers, M. (2014) The Structural Organization of NGO Publicity Work: Explaining Divergent Publicity Strategies at Humanitarian and Human Rights Organizations. International Journal of Communication, 8: 90-107.

Robinson, P. (2002) The cNN Effect. The Myth of News, Foreign Policy and Intervention. Routledge.

Singer, P. (1972) Famine, Affluence, and Morality. Philosophy and Public Affairs, 1(3): 229-243.

\title{
Medical Neutrality
}

Medical neutrality refers to the principle of non-interference with medical services during conflicts and other humanitarian crises. The concept of medical neutrality is grounded in statutes in international humanitarian law (IHL) and international human rights law, and is informed by ethical codes such as the Hippocratic Oath (Bouchet-Saulnier et al. 2013; Roberts and VanRooyen 2013). It requires three things: (1) the protection of and non-interference with the operations of medical facilities, medical transport, and medical personnel; (2) the provision of the best medical care possible to all who need medical attention, combatants and non-combatants alike, regardless of their political affiliation or participation in conflicts and politics; and most generally, (3) the mandate that warring factions both protect and refrain from targeting civilians during conflicts. Numerous non-governmental aid and human rights organizations, United Nations agencies, and state signatories to international laws and treaties support and variably enact the principle of medical neutrality. For example, alongside the International Committee of the Red Cross (ICRC), Physicians for Human Rights has led many initiatives to define and enforce medical neutrality.

The four Geneva Conventions, which allude to the idea of medical neutrality, were ratified in 1949. Protocols I and II were added in 1977 to, among other things, specify the meaning of medical neutrality and more generally expand the application of I HL to account for the nature of 2oth-century conflicts. Protocol I sets out new rules regarding the treatment of the deceased, the protection and care for civilians and prisoners involved in and affected by conflicts, and the protection of all forms of medical units and personnel. Protocol II adds the protection of victims of non-international and internal armed conflicts to those already covered within the laws of war. These additional protocols 
have been ratified by 168 countries, excepting several countries including Iran, Iraq, Israel, North Korea, Pakistan, Syria, Turkey, and the United States. Benton and Atshan (2016:153) argue that these legal and clinical artifacts "were developed in the interests of state power" and serve political ends.

Violations of medical neutrality occur when, for instance, civilians, medical facilities, and medical personnel are deliberately targeted in conflict. In recent years, the armed forces of several countries have repeatedly and deliberately targeted civilian and medical infrastructures such as hospitals and ambulances, and have strategically obstructed and corrupted the flow of medical supplies (Hamdy and Bayoumi 2016). National militaries now undermine the provision of health care to oppositional groups by retaliating against the health professionals who treat the sick and wounded, for example in Syria. Access to populations in need, medical facilities, and medical supplies are sometimes controlled by parties to conflict, forcing humanitarian organizations and medical providers to partner with them and funnel aid through partisan affiliates (Sparrow 2018). While violations of medical neutrality can rise to the level of war crimes, there are few mechanisms to enforce or punish the actors involved. During periods of civil unrest, violations of medical neutrality can infringe important human rights treaties such as the International Convention on Civil and Political Rights and the Convention Against Torture, but again, there are few mechanisms through which victims can seek justice.

There remains a tension between the principle and operational necessity of medical neutrality legally required of state actors and intervening aid organizations, and the principle of medical neutrality and activism on behalf of patients practiced by individuals who provide medical care and protection during humanitarian emergencies (Allhoff 2008). This tension, referred to as "the problem of neutrality" by Peter Redfield (2013), has been central to the differences in missions and practices of organizations such as Médecins Sans Frontières and the ICRC that hire and deploy clinical medical providers during conflicts. Ethnographies of medical care in conflict provide a window into these tensions, and into how medical neutrality is variably socially and politically constructed and debated by different individuals within different aid and donor organizations - especially various medical providers involved in humanitarian response. For example, Hamdy and Bayoumi (2016) and Aciksoz (2016) demonstrate that while clinical providers provide a unique witness to the physical toll of conflict on the bodies of their patients in Egypt and Turkey respectively, these clinicians also use their position as "neutral" actors as a political stance from which to advocate for social and political change. Their neutrality, in these cases, is not apolitical, exceptional, or immune from the 
conflicts at hand, but rather explicitly and strategically political and engaged in advocacy on behalf of patients.

\section{Lauren Carruth}

\section{References}

Aciksoz, S.C. (2016) Medical Humanitarianism under Atmospheric Violence: Health Professionals in the 2013 Gezi Protests in Turkey. Culture, Medicine, and Psychiatry, 40(2): 198-222.

Allhoff, F. ed. (2008) Physicians at War: The Dual-Loyalties Challenge. Springer.

Benton, A., Atshan, S.E. (2016) "Even War Has Rules": On Medical Neutrality and Legitimate Non-Violence. Culture, Medicine and Psychiatry, 40(2): 151-158.

Bouchet-Saulnier, F. et al. (2013) The Practical Guide to Humanitarian Law. Médecins Sans Frontières, Rowman \& Littlefield Publishers.

Hamdy, S.F., Bayoumi, S. (2016) Egypt's Popular Uprising and the Stakes of Medical Neutrality. Culture, Medicine, and Psychiatry, 40(2): 223-241.

Redfield, P. (2013) Life in Crisis: The Ethical Journey of Doctors Without Borders. University of California Press.

Roberts, L.F., VanRooyen, M.J. (2013) Ensuring Public Health Neutrality. New England Journal of Medicine, 368: 1073-1075.

Sparrow, A. (2018) How UN Humanitarian Aid Has Propped Up Assad: Syria Shows the Need for Reform. Foreign Affairs, September 20.

\section{Mental Health}

The nexus of humanitarianism and mental health has gained traction in regard to environmental, political, and epidemiological situations. Humanitarian frameworks of response, assistance, relief, and aid have been operationalized heterogeneously around disruptions to mental health caused by conflict, war, environmental disaster, climate change impacts, poverty, and displacement. The deleterious effects of these factors on clinical and subclinical forms of suffering have been targeted, and the enhanced ability of health services to deliver care has been sought.

Mental health and humanitarianism foster collaborations between social scientists, medical practitioners, lawyers, politicians, anthropologists, and 